\title{
Phaeocystis antarctica blooms strongly influence bacterial community structures in the Amundsen Sea polynya
}

\author{
Tom O. Delmont ${ }^{1}$, Katherine M. Hammar ${ }^{1}$, Hugh W. Ducklow ${ }^{2}$, Patricia L. Yager ${ }^{3}$ and Anton F. Post ${ }^{1 *}$ \\ ${ }^{1}$ Marine Biology Laboratory, Josephine Bay Paul Center for Comparative Molecular Biology and Evolution, Woods Hole, MA, USA \\ ${ }^{2}$ Lamont Doherty Earth Observatory, Columbia University, Palisades, NY, USA \\ ${ }^{3}$ Department of Marine Sciences, University of Georgia, Athens, GA, USA
}

\section{Edited by:}

Lois Maignien, University of

Western Brittany, France

Reviewed by:

Jean-Baptiste Ramond, University of

Pretoria, South Africa

C. N. Shulse, University of Hawai'i

at Manoa, USA

Meghan Chafee, Max Planck

Institute for Marine Microbiology,

Germany

${ }^{*}$ Correspondence:

Anton F. Post, Marine Biological

Laboratory, Josephine Bay Paul

Center for Comparative Molecular

Biology and Evolution, $7 \mathrm{MBL}$

Street, Woods Hole, MA 02543,

USA

e-mail:apost@mbl.edu
Rising temperatures and changing winds drive the expansion of the highly productive polynyas (open water areas surrounded by sea ice) abutting the Antarctic continent. Phytoplankton blooms in polynyas are often dominated by the haptophyte Phaeocystis antarctica, and they generate the organic carbon that enters the resident microbial food web. Yet, little is known about how Phaeocystis blooms shape bacterial community structures and carbon fluxes in these systems. We identified the bacterial communities that accompanied a Phaeocystis bloom in the Amundsen Sea polynya during the austral summers of 2007-2008 and 2010-2011. These communities are distinct from those determined for the Antarctic Circumpolar Current (ACC) and off the Palmer Peninsula. Diversity patterns for most microbial taxa in the Amundsen Sea depended on location (e.g., waters abutting the pack ice near the shelf break and at the edge of the Dotson glacier) and depth, reflecting different niche adaptations within the confines of this isolated ecosystem. Inside the polynya, $P$. antarctica coexisted with the bacterial taxa Polaribacter sensu lato, a cryptic Oceanospirillum, SAR92 and Pelagibacter. These taxa were dominated by a single oligotype (genotypes partitioned by Shannon entropy analysis) and together contributed up to $73 \%$ of the bacterial community. Size fractionation of the bacterial community $[<3 \mu \mathrm{m}$ (free-living bacteria) vs. $>3 \mu \mathrm{m}$ (particle-associated bacteria)] identified several taxa (especially SAR92) that were preferentially associated with Phaeocystis colonies, indicative of a distinct role in Phaeocystis bloom ecology. In contrast, particle-associated bacteria at $250 \mathrm{~m}$ depth were enriched in Colwellia and members of the Cryomorphaceae suggesting that they play important roles in the decay of Phaeocystis blooms.

Keywords: Amundsen Sea polynya, phytoplankton bloom, Phaeocystis antarctica, microbial community structure, mutualism

\section{INTRODUCTION}

Phytoplankton blooms account for a significant fraction of marine primary production. Such blooms occur in the open ocean [e.g., by the cyanobacterium Trichodesmium (Capone et al., 1997, 2005) or the diatoms Hemiaulus and Rhizoselenia (Subramaniam et al., 2008)] as well as in the coastal ocean (e.g., Karenia, Pseudonitzschia), where they can be a nuisance for aquaculture and fisheries. Bloom events continue to intrigue ocean researchers as the physiological underpinnings of their development, duration and demise remain unresolved (Behrenfeld and Boss, 2014). Species like Trichodesmium create short-lived (10-20 days) blooms of the rise-and-crash type, whereas blooms of other species may be sustained over considerably longer periods (1-3 months). The haptophyte Phaeocystis is a ubiquitous marine phytoplankter that causes blooms in coastal seas. Species contained in this genus have typical geographic distributions with $P$. pouchetii dominating in the Arctic Ocean, P. globosa in temperate coastal seas and $P$. antarctica occupying diverse niches in the Southern Ocean, respectively (Schoemann et al., 2005). Phaeocystis blooms significantly impact local carbon, nutrient and sulfur cycles (Van Boekel and Stefels, 1993; Yager et al., 2012) and can disturb ecosystems (Chen et al., 1999).

Extensive phytoplankton blooms occur in Antarctic waters (Arrigo and Van Dijken, 2003). In explored Antarctic polynyas (large open water expanses in sea ice), blooms are often dominated by P. antarctica (Arrigo et al., 1999; Smith et al., 2000; Yager et al., 2012; Kim et al., 2013). These populations are generally limited by light and iron availability (Martin et al., 1990; Bertrand et al., 2011a; Alderkamp et al., 2012) and bloom formation occurs when environmental conditions become favorable (Zingone et al., 1999; Smith et al., 2003; Vogt et al., 2012). The duration and scale of these favorable conditions are enhanced by rising temperatures and winds (Arrigo et al., 1998; Turner et al., 2005; Yager et al., 2012). Phaeocystis blooms occur in the surface mixed layer and they can span much of the austral summer (Arrigo et al., 1999; Wolf et al., 2013). Their populations rapidly draw down $\mathrm{CO}_{2}$ concentrations to $<100 \mathrm{ppm}$ (Arrigo and Van Dijken, 2003; Yager et al., 2012). Thus, Phaeocystis blooms supply 
organic carbon and nutrients to the food web inside polynyas (Rousseau et al., 2000; Kirchman et al., 2001a; Ducklow, 2003) and provide ecological niches for microbial heterotrophs (e.g., those capable of degrading particle organic carbon). The requirement for a continued supply of essential nutrients and growth factors like vitamins (Bertrand et al., 2011b), along with the removal of metabolites and exudates that negatively affect algal growth, likely influence bloom intensity and duration in most water bodies. The mechanisms by which Phaeocystis blooms sustain their activity over time are not well understood and possibly involve important functional interactions with their surrounding microbial community.

Bacteria entertain a wide range of interactions with phytoplankton (Cole, 1982; Doucette, 1995; Croft et al., 2005; Sher et al., 2011), and these interactions in turn may determine the composition of the bacterial community. A succession of bacterial taxa was observed during a phytoplankton bloom in the North Sea and their occurrence patterns were linked to their ability to degrade algal-derived organic matter (Teeling et al., 2012). The final phase of the bloom was shown to favor Ulvibacter and Formosa dominance during early and mid-stages of the decline, and to Polaribacter in the final stages. Polaribacter abundances correlate positively with chlorophyll a concentrations in the Southern Ocean and they play an active role in remineralizing organic matter generated from primary production during bloom events (Wilkins et al., 2013b; Williams et al., 2013). Not only is the free-living bacterial community affected by phytoplankton blooms, the bacterial epibionts that reside on algal cells or colonies alter their community structure as a phytoplankton bloom progresses. For example, Trichodesmium colonies have an epibiotic bacterial flora that is distinct from the free-living bacterial community (Hmelo et al., 2012). These changes in community structure are in part driven by chemotactic responses of bacterial taxa to phytoplankton exudates like dimethylsulfoniopropionate (Stocker et al., 2008; Seymour et al., 2010; Stocker and Seymour, 2012). Quorum sensing by associated bacteria was shown to enhance phosphate scavenging by Trichodesmium (Van Mooy et al., 2011).

$P$. antarctica blooms consist mostly of colonies that reach a diameter of a few millimeters and can be identified by the naked eye (Carlson et al., 1998; Smith et al., 1998). They form an important interface between the primary producers and their environment. The mucilaginous colony matrix that encapsulates the Phaeocystis cells forms a barrier for the exchange of dissolved compounds but it may also provide a habitat for bacterial species. Previous studies suggest that $P$. antarctica blooms affect microbial community structure in their immediate surroundings. An iron-induced phytoplankton bloom study in the Southern Ocean (West et al., 2008) showed that Roseobacter, SAR92 and Bacteroidetes dominated the bacterial community inside the bloom, whereas outside the bloom SAR11, Polaribacter and different Roseobacter types were more prevalent. A metagenomic study of coastal waters near the Antarctic Peninsula showed that bacterial communities were dominated by genotypes capable of chemotrophic, photoheterotrophic and aerobic anoxygenic photosynthetic metabolism (Grzymski et al., 2012). These communities were rich in SAR11-like genotypes, but poor in Bacteroidetes and Gammaproteobacteria (Grzymski et al., 2012). The Amundsen Sea polynya (ASP) is dominated by Polaribacter spp. (Bacteroidetes) and Oceanospirillales (Gammaproteobacteria) members (Ghiglione et al., 2012; Kim et al., 2013; Richert et al., submitted). These studies also reported different bacterial communities in areas with ice cover as compared to open water samples. Likewise, iceberg melt affects bacterial communities with Gammaproteobacteria dominating deep waters near icebergs and Bacteroidetes dominating elsewhere (Dinasquet et al., submitted). In accordance with findings elsewhere (Piquet et al., 2011), bacterial abundances in the ASP were highly correlated with Phaeocystis and diatoms suggesting a close coupling between the phytoplankton and bacterial communities (Kim et al., 2013). Bacterial productivity is not only higher in the open polynya as compared to adjacent water bodies, the bulk of bacterial exoenzyme activity, respiration and production was associated with the size fraction that contains Phaeocystis particles (Williams et al., submitted). However, so far no efforts have been made to assess whether members of the bacterial community interact directly with Phaeocystis. We hypothesized that the bacterial community is not limited to the biomineralization of organic carbon and nutrients but that specialized members of this community may also entertain interactions with Phaeocystis that stimulate bloom formation or act to enhance and perpetuate such blooms.

In an attempt to investigate the occurrence of such interactions we sampled two $P$. antarctica bloom events (2007-2008 and 2010-2011) from the highly productive ASP in west Antarctica (Arrigo and Van Dijken, 2003; Alderkamp et al., 2012; Mills et al., 2012). We targeted the V6 hypervariable region of the 16S rRNA gene with primers that target bacterial and eukaryotic organelle templates. We used this approach to generate large V6 sequence datasets $\left(10^{5}-10^{6}\right.$ reads per sample) for various locations at the shelf break, inside the polynya and near the Dotson glacier. We coupled the depth and quality of paired-end Illumina sequencing to oligotyping, a sensitive bioinformatics tools to partition conserved genotype clusters within key microbial taxa, revealing an extended diversity. Using different sampling strategies, we discovered a number of bacterial taxa that preferentially associate with $P$. antarctica and their abundance correlated with that of Phaeocystis. We also identified different bacterial taxa that may play a specific role in bloom demise and the degradation of Phaeocystis biomass at depth.

\section{MATERIALS AND METHODS}

Water samples were collected at various sites across the ASP during the austral summers of 2007-2008 (aboard the icebreaker R/V "Oden"; depth profiles) and 2010-2011 (ASPIRE cruise aboard the R/V "Nathaniel B Palmer," horizontal grid of surface samples) (Figure 1, Table S1). Cruise track, sampling sites and an overview of geochemical and biological properties have been detailed elsewhere (Yager et al., 2012). Additional information can be found in the BCO-DMO database (http://osprey. bco-dmo.org/project.cfm?id=146\&flag=view) and in Table S2. For the 2010-2011 cruise, water samples (3-10 L) for microbial community sequence analyses were passed over a $20 \mu \mathrm{m}$ mesh and collected onto $0.2 \mu \mathrm{m}$ Sterivex membrane filter cartridges by 


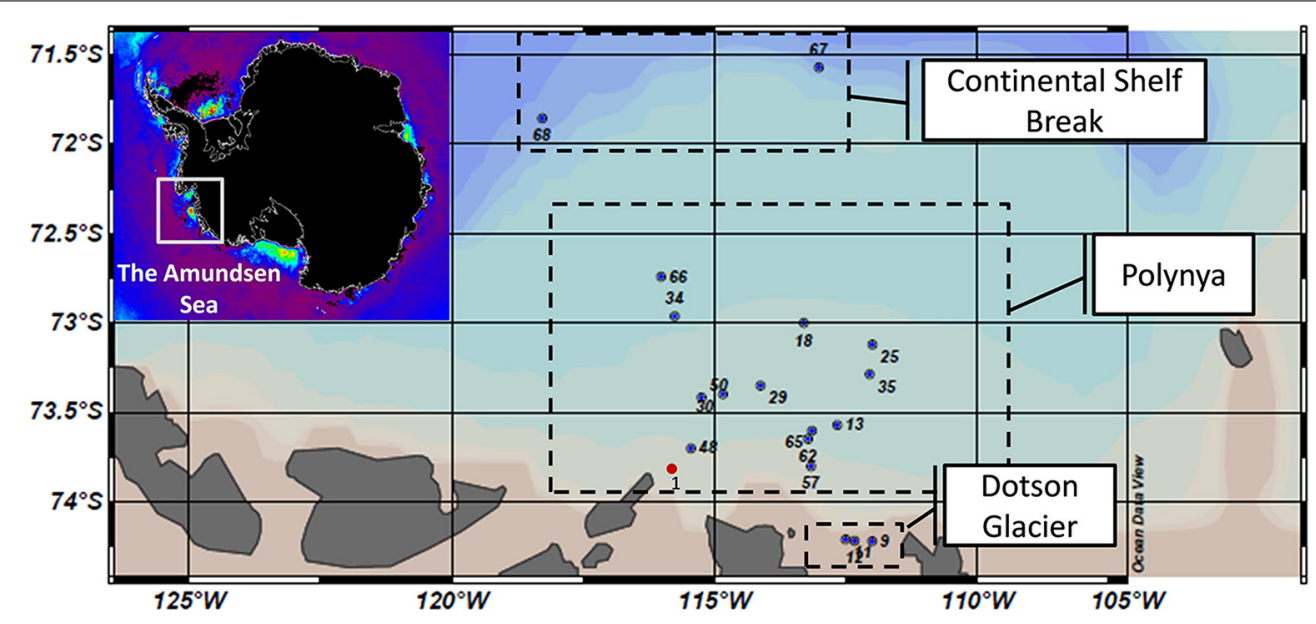

FIGURE 1 | Map of sampling sites across the Amundsen Sea polynya that were visited during the Oden Southern Ocean (OSO) cruise in 2007-2008 (red dot) and the ASPIRE cruise in 2010-2011 (blue dots). Samples were grouped into three major regions: the Continental Shelf Break, the open waters of the polynya and waters abutting the Dotson Glacier. Insert: A map of chlorophyll a concentrations (red: high; purple: low) in polynyas abutting the Antarctic continent as estimated by remote sensing (courtesy of Dr. Kevin R. Arrigo, Stanford University). Note that sample numbers are only informative of the station number tracked during the ASPIRE cruise. The corresponding samples are presented in the supplemental material. pressure filtration (Whatman Masterflex L/S series). Since high biomass caused rapid clogging of the filters, the sampling volumes varied between stations. Two distinct plankton size classes $(0.2-$ $3 \mu \mathrm{m}$ and 3-200 $\mu \mathrm{m}$ ) were fractionated for samples collected during the 2007-2008 cruise. This sampling effort (10-20 L) was done along a depth profile that spanned the full water column (Figure 1, Table S1) and the microbial community analysis was part of the International Consensus for Marine Microbes project. Filters were quickly frozen in the headspace of a $\mathrm{LN}_{2}$ Dewar and stored at $-80^{\circ} \mathrm{C}$ prior to DNA extraction. We note that the 2007-2008 data were determined on samples from a single depth profile inside the ASP. It was decided to incorporate these data in order to derive first hints regarding the reproducibility of bacterial community compositions that accompany Phaeocystis blooms in the ASP and to gain early insights into the bacterial taxa that may associate with Phaeocystis colonies and other particles. Metadata of the various samples are presented in Table S1 and in the supplemental material. DNA extraction was performed using the Puregene kit $\left(\right.$ Gentra $\left.^{\circledR}\right)$ after disruption of the cells with lytic enzyme coupled to proteinase K (Sinigalliano et al., 2007). DNA concentrations were quantified using a Nanodrop 2000 instrument (Thermo Fisher Scientific, Wilmington, DE).

The V6 hypervariable region of the $16 \mathrm{~S}$ rRNA gene (typically $60-65$ bp in length) was amplified ( 25 cycles using HiFi buffer $1 \mathrm{X}$, $\mathrm{MgSO}_{4} 2 \mathrm{mM}$, dNTPs $0.2 \mathrm{mM}$, combined primers $0.2 \mathrm{mM}$ and four units of platinum $\mathrm{HiFi}$ ) in triplicate PCR reaction from $10 \mathrm{ng}$ of environmental DNA templates with reverse primer (1046R) "CGACRRCCATGCANCACCT" and the forward primer mix (967F) "CTAACCGANGAACCTYACC," "ATACGCGARGAACC TTACC," "CNACGCGAAGAACCTTANC," and "CAACGCGM ARAACCTTACC." PCR cycle conditions were defined as follow: $30 \mathrm{~s}$ at $94^{\circ} \mathrm{C}$ followed by $45 \mathrm{~s}$ at $60^{\circ} \mathrm{C}$ and $1 \mathrm{~min}$ at $72^{\circ} \mathrm{C}$. The PCR started with $3 \mathrm{~min}$ at $94^{\circ} \mathrm{C}$ and ended with $2 \mathrm{~min}$ at $72^{\circ} \mathrm{C}$ followed by a rapid stepdown to $4^{\circ} \mathrm{C}$. Negative controls (no template DNA) were run for each of the index primer combinations in the PCR reactions. V6 amplicon sequences from samples collected during the 2007-2008 R/V "Oden" cruise $(n=12)$ were obtained on a GS-FLX pyrosequencing platform. Sequence reads were subsequently trimmed for low-quality sequences (Huse et al., 2007). For samples collected on the ASPIRE cruise during the 20102011 austral summer $(n=23)$, a paired-end sequencing strategy for Illumina Hiseq platform was employed with custom fusion primers described previously (Eren et al., 2013b) targeting the V6 hypervariable region of the $16 \mathrm{~S}$ rRNA gene. The library design provided a complete overlap of the V6 region, and high-quality V6 reads were generated by requiring a complete match between the two reads of each pair (Eren et al., 2013b). Read sizes of the trimmed datasets are presented in Table $\mathbf{S 1}$.

Quality-filtered datasets were subsequently annotated using the Global Assignment of Sequence Taxonomy (GAST) pipeline (Huse et al., 2008) using the SILVA 111 database for reference (Quast et al., 2013). The datasets are publically accessible through the VAMPS website (http://vamps.mbl.edu/) under the project names ICM_ASA_Bv6 (2007-2008) and AFP_ASPIR_Bv6 (20112012). In order to assess within taxon diversity, reads affiliated to a given genus with GAST were submitted to oligotyping, a computational method for taxonomical partitioning based on Shannon entropy decomposition (Eren et al., 2013a). By utilizing only the nucleotide positions that show high variation, and disregarding the redundant sites with low entropy, oligotyping analysis employs only a fraction of the nucleotide positions across the read length, hence reduces the impact of random sequencing errors while maintaining high sensitivity to discriminate closely related but distinct taxa. STAMP software (Parks and Beiko, 2010) was used to observe taxonomical structure variations inferred from $16 \mathrm{~S}$ rRNA gene amplicon datasets. Furthermore, principal 
component and correspondence analyses were performed using the "R" and Ade4TkGUI software packages (Thioulouse et al., 1997). Box plots were generated using R. A Pearson statistical test was used to study the correlation of specific microbial taxa among the datasets. Finally, One-Way ANOVA tests were used to access the significance of community structure shifts observed between groups of samples.

\section{RESULTS}

\section{DISTANT LOCALES IN THE SOUTHERN OCEAN HAVE DISTINCT MICROBIAL COMMUNITIES}

During the 2010-2011 austral summer, surface water samples were collected at 18 sites (plus 5 near-bottom water samples for a total of 23 samples) across the ASP (Figure 1): 3 sites along the Dotson glacier, 2 sites covered by pack ice at the outer fringe of the polynya near the shelf break and 13 sites

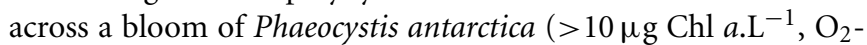
saturation at $>400 \%, \mathrm{pCO}_{2} 100-250 \mathrm{ppm}$ ) in the open waters of the polynya. Bacterial community structures $(0.2-20 \mu \mathrm{m})$ were determined by deep sequencing of $16 \mathrm{~S}$ rRNA amplicons [6065 nucleotides of the V6 hypervariable region, $>10^{5}$ reads per sample (Table S1)]. Even though our primer sets amplified some Archaea V6 (and thus provided an approximation of their diversity) we did not include these data here. The diversity and low abundance of Archaea in the ASP center (Archaea/Bacteria ratio of about 1/500) was part of a separate study (Kim et al., 2013). Our observations on the microbial community structures focused on the diversity, relative abundance and distribution of bacterial and eukaryotic taxa.

In a first approach we compared the bacterial communities of four randomly selected ASP surface samples [Ant11, Ant13, Ant14, Ant15 (Table S1)] with those determined for four surface water samples from the Antarctic Circumpolar Current (ACC) and four samples near the Antarctic Peninsula (Sul et al., 2013). Figure S1 shows a heat map comparison of these different sites. It is immediately apparent that the microbial community structures had a high degree of similarity within datasets for each of the three locales in the Southern Ocean, but substantial dissimilarity was noted between datasets. The bacterial communities in the ASP were most dissimilar from those at the two other locales. The Bray-Curtis dissimilarity index for samples inside the ASP was only $0.27 \pm 0.13$. However, the dissimilarity index increased substantially when comparing different locales: $0.54 \pm$ 0.06 between ASP and ACC; $0.64 \pm 0.04$ between ASP and waters off the Antarctic Peninsula.

A more detailed visualization of the difference among the bacterial communities from the three locales is presented in Figure 2. Whereas the deep samples (most diverse) populated the left two quadrants of both the Principal Component Analysis (PCA) and Correspondence Analyses plots, surface samples (less diverse) organized along the central axis with the exception of the samples that represent the surface waters in the center of the polynya where the P. antarctica bloom occurred (Figure 2, Figure S2). The latter samples all grouped together in a cluster distant from the other samples. The axes in the PCA plot account for about 48\% of the total variance. These differences were mainly driven by a dominant contribution of Pelagibacter ( $>10 \%$ of total), SAR86, members of the Gamma-Proteobacteria and Rhodobacteraceae (each at 1-10\%) in the ACC samples. In contrast, bacterial communities in surface waters of the central polynya were dominated by a large group of Flavobacteria, Oceanospirillales, SAR92 and Ulvibacter ( $>1 \%$ total) with a minor but significant contribution $(<1 \%)$ made by Lutibacter, Crocinotimix, Roseobacter and members of the Cryomorphaceae. The microbial community that accompanied the $P$. antarctica bloom was different from those near the Dotson glacier or at the outer fringes of the polynya near the shelf break.

\section{MICROBIAL COMMUNITY STRUCTURE INSIDE THE AMUNDSEN SEA POLYNYA}

To better understand differences in microbial communities at different locations in the Amundsen Sea we analyzed the taxonomic composition of Eukarya and Bacteria across the polynya. On average, $1.58 \pm 0.72$ and $0.015 \pm 0.009 \mu \mathrm{g} \mathrm{L}^{-1}$ of DNA were extracted from surface and deep samples, respectively. DNA yields were two orders of magnitude lower in the deeper samples, reflecting the lower biomass levels of this size fraction at depth (Figure 3A). Eukarya ( $>99 \%$ phytoplankton taxa) were an important fraction in surface waters (Figure 3B), most prominent near the Dotson glacier $(62 \pm 5.8 \%)$. Bacteria made up the bulk of the community in deep samples $(94 \pm 1.8 \%)$ where the number of detected species $(576 \pm 131)$ significantly increased $(p<0.001)$ in comparison to surface samples $(361 \pm 51)$ (Figure S3). Among the Eukarya, haptophyte (>99\% Phaeocystis antarctica) genotypes dominated the phytoplankton bloom in the ASP (72 $\pm 7.8 \%)$ while diatoms (Bacillariophyta) were more abundant near the Shelf break and the Dotson glacier (70 $\pm 12 \%$, see Figure 3C). Note that $16 \mathrm{~S}$ rRNA gene copy number can vary widely between alga species depending on the number of chloroplasts per cell. Therefore, the ratio of Bacteria/Eukarya and haptophyte/diatoms in each dataset are not necessary representative of the plankton community structure. On the other hand, ratio differences observed for the same populations between samples are more likely to reflect shifts in community structure. In particular, we observed a clear shift from a Proteobacteria dominated bacterial community $(73 \pm 11.2 \%$ vs. $50 \pm 8.3 \%, p<0.001)$ outside the $P$. antarctica bloom to a Bacteroidetes dominated community $(47 \pm 8 \%$ vs. $18 \pm 13.1 \%, p<0.001)$ inside the bloom. The abundant Phaeocystis populations in central waters of the polynya were accompanied by a bacterial community dominated by Flavobacteria ( $99 \pm 0.8 \%$ of total Bacteroidetes), and Proteobacteria. Together they contributed $>95 \%$ of the V6 reads in each of the polynya samples (Figure 3D). Inside the polynya the Proteobacteria were dominated by Gammaproteobacteria (73 $\pm 6.2 \%$, mostly Oceanospirillum-like and SAR92) and Alphaproteobacteria ( $24 \pm 6.2 \%$, mostly Pelagibacter) with lesser contributions made by Betaproteobacteria (1.2 $\pm 1.1 \%$, mostly Methylophilaceae), Deltaproteobacteria $(0.7 \pm 0.4 \%)$ and few Epsilonproteobacteria $(0.0006 \pm 0.004 \%)$. We also explored a dataset from another bloom event (R/V Oden cruise, 2007-2008) that was sampled along a single depth profile (Table S1) and we compared their microbial communities. Four samples that originated from the upper $100 \mathrm{~m}$ of the water column and that had Chl a concentrations of $>8 \mu \mathrm{g} \mathrm{L}^{-1}$ all revealed microbial community 




FIGURE 2 | Principal component analysis (euclidean distance) of the relative distribution of the $\mathbf{3 6}$ most abundant bacterial taxa across high throughput sequencing datasets from the Southern Ocean (Antarctic Circumpolar Current) and the Amundsen Sea (shelf break, Dotson glacier and polynya). The latter includes surface and deep bacterial communities sampled at the outer rim of the polynya, near the Dotson
Glacier and in the open waters of the polynya. Pyrosequencing datasets of the Amundsen Sea polynya representing the 0.2-3 $\mu \mathrm{m}$ size fraction sampled during the 2007-2008 bloom event (4 surface and 3 deep samples; see Table S1) were included in the analysis. Orange labels denote taxa that contribute $>10 \%$ of the bacterial community; green denotes $1-10 \%$; Blue is $<1 \%$. structures that were highly similar to those of the 2010/2011 bloom (see Figure 2).

In contrast to the surface samples the bacterial communities in deep samples (Figure 3D) were characterized by an increased contribution of Proteobacteria $(80 \pm 6.1 \%)$ and decreasing Bacteroidetes abundances $(8.3 \pm 2.9 \%)$. Both the increase in the prevalence of Proteobacteria and the decrease in Bacteroidetes abundance were significant $(p<0.01)$ in One-Way ANOVA tests. Verrucomicrobia $(3.0 \pm 1.4 \%)$ and Actinobacteria $(4.7 \pm$ $1.8 \%$ ), typically found in deep marine waters (Sogin et al., 2006; Quaiser et al., 2008; Freitas et al., 2012), were significantly more abundant in deep samples (Figure 3D). The Proteobacteria were dominated by Gammaproteobacteria ( $47 \pm 14.6 \%$, mostly Pseudoalteromonas and Oceanospirillales), Alphaproteobacteria $(33 \pm 15.6 \%$, mostly Pelagibacter and SAR11 related taxa) and Deltaproteobacteria (19 $\pm 5.7 \%$, mostly SAR324 and Nitrospina) with a minor contributions made by Betaproteobacteria $(0.4 \pm$ $0.3 \%)$ and Epsilonproteobacteria $(0.2 \pm 0.1 \%)$ classes. The Delta and Epsilon classes were therefore drastically more represented in deep samples. Three samples from 250 to $785 \mathrm{~m}$ depth within the polynya water column and collected during the 2007-2008 bloom event provide similar trends (these samples are part of the "Polynya deep" group in Figure 2), with a dominance of
Pelagibacter, Oceanospirillales and SAR324 genotypes. Altogether, our findings indicate that the surface and deep microbial community structures of the Amundsen Sea polynya were highly similar across the spatial dimensions of the bloom. They were also maintained across temporal scales that exceed bacterial generation times by far. We note that these highly similar bacterial communities were maintained over a 18 day period (19/12/2010 to $05 / 01 / 2011$ ), close to the climax of the $\sim 90$ day bloom duration estimated from remote sensing images (Arrigo and Van Dijken, 2003).

\section{OLIGOTYPE DIVERSITY OF BACTERIAL AND EUKARYOTIC TAXA}

In order to analyze the bacterial communities in more detail we studied the diversity of selected taxa across the polynya during the 2010-2011 bloom event (Figures 4-6). Shannon entropy decomposition or oligotyping (Eren et al., 2013a) was used to track subtle, conserved sequence variations and differentiate genotypes that make up each taxon but differ by as few as 1-7 nucleotides. Among the chloroplast V6 reads, those identified as Phaeocystis antarctica were dominated by a single oligotype (>90\%) at all locations and depths inside the polynya (Figure 4). A few different oligotypes were distinct in surface waters near the shelf break, suggesting the existence of sub-populations of $P$. antarctica 


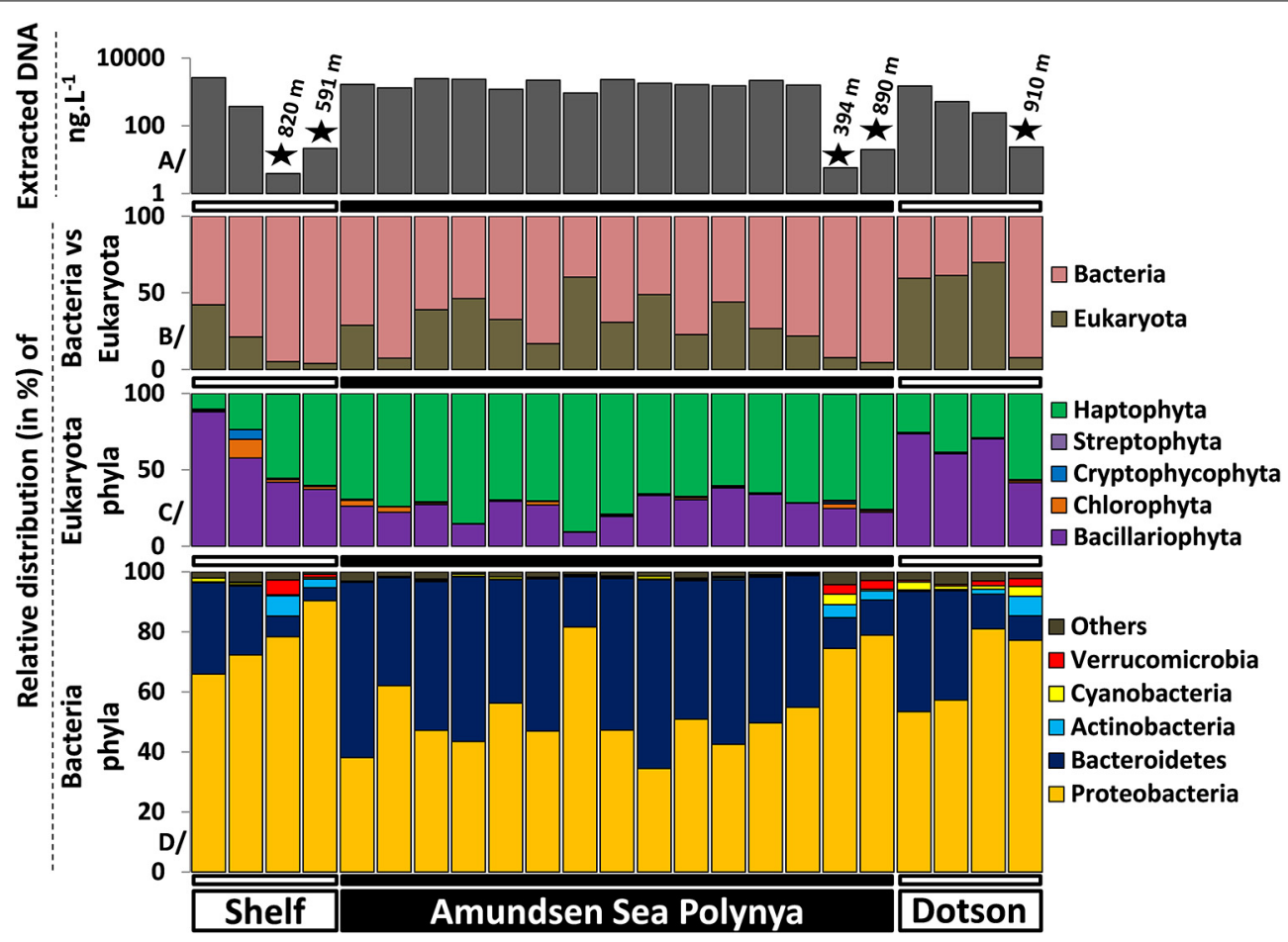

FIGURE 3 | Microbial community structures determined by Illumina sequencing ( $>10^{5}$ reads per sample) of 16S-V6 rRNA amplicons obtained from surface and deep samples at sites with dense ice cover at the shelf break (Shelf), inside the Amundsen Sea polynya and in open waters adjacent to the Dotson glacier (Dotson) during a Phaeocystis antarctica bloom in 2010-2011. (A) (top) denotes the concentration of extracted DNA for each sample as a proxy for microbial biomass; the " $\star$ " symbols denote deep (>350 m) samples. The relative contribution of Bacteria vs. Eukaryota (chloroplast 16S) is presented in (B). (C,D) present the phytoplankton and bacterioplankton community composition at the phylum level.

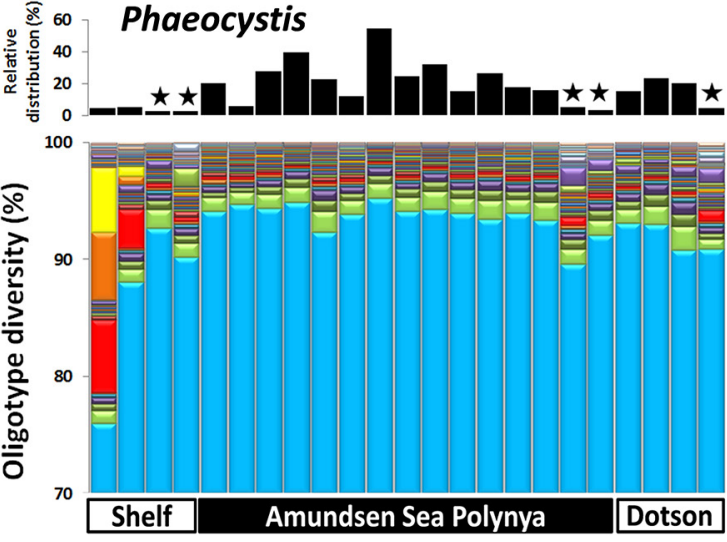

FIGURE 4 | Phytoplankton oligotype diversity of 16S-V6 rRNA amplicon sequences obtained for Phaeocystis (left graph) and diatoms (right graph). Surface and deep samples were obtained at sites with dense ice cover at the shelf break (Shelf), inside the Amundsen Sea polynya and in open waters adjacent to the Dotson



glacier (Dotson) during a Phaeocystis antarctica bloom in 2010-2011. Panels at top of the graphs denote the relative contribution of a taxon within each dataset; the " $\star$ " symbols denote deep (>350 m) samples. Oligotypes detected at low abundance $(n<200)$ in the dataset were removed from the analysis. that do not contribute to bloom formation. Diatom populations were more diverse (Figure 4). Among the bacterial V6 reads, the major taxa in surface layers of the polynya were dominated by a single oligotype for SAR92 (97 $\pm 1.8 \%$ of total),
Oceanospirillum-like bacteria $(95 \pm 1.4 \%)$, Pelagibacter $(80 \pm$ $7.3 \%$, data not shown) and members of the Flavobacteriaceae $(75 \pm 14.1 \%)$ a family for which V6 sequence do not allow taxonomy assignment below the rank of family (Figure 5 ). These 
taxa showed different oligotype diversity patterns in deep samples with the exception of the Oceanospirillum-like oligotype diversity that remained strikingly similar despite the strong variation in their relative abundance $(0.9-33.9 \%$ of the bacterial community) across the datasets. The dominant oligotype related to Flavobacteriaceae could not be resolved taxonomically due to a perfect match between V6 sequences of Polaribacter and other members of the Flavobacteriaceae. This oligotype was therefore denoted as Polaribacter sensu lato. On the other hand, taxa such as SAR86, Nitrospina and Verrucomicrobia that were detected in higher abundance outside the bloom (especially in deep samples) were more diverse and lacked a single dominant representative oligotype for either of the niches (Figure 5). For SAR86, one oligotype dominated the deep samples while another oligotype was more abundant in the surface waters at the shelf break. The two oligotypes represent bacteria that have so far evaded successful cultivation. Nitrospina was equally diverse in all samples except at the shelf break where we observed a few distinct oligotypes. Finally, the diversity among Verrucomicrobia genotypes appeared to be relatively uniform across all datasets with minor variations observed between different locales.
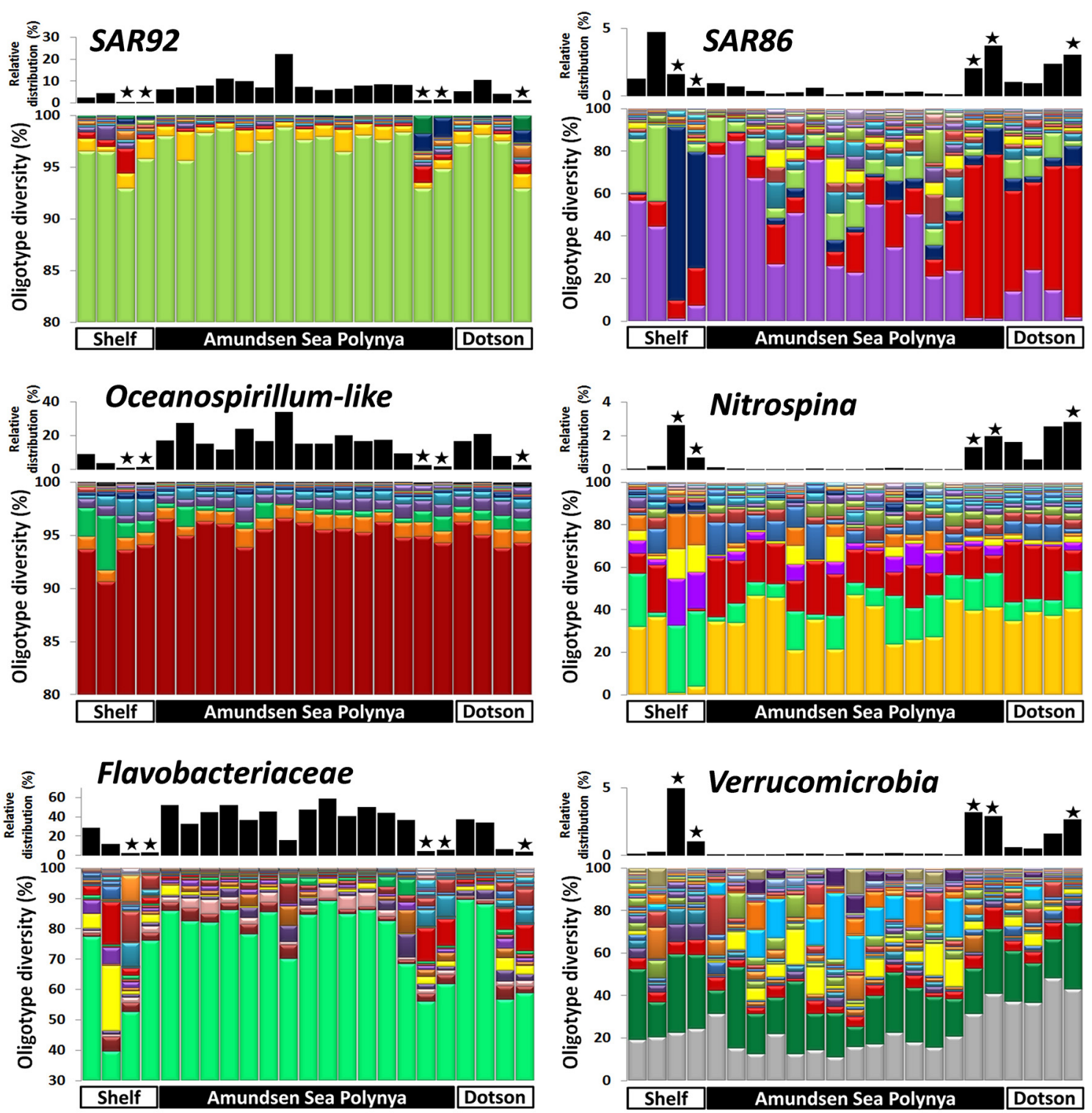

FIGURE 5 | Bacterial oligotype diversity of 16S-V6 rRNA amplicon sequences obtained for taxa that dominated inside (left graphs) and outside (right graph) the Phaeocystis surface bloom. Surface and deep samples were obtained at sites with dense ice cover at the shelf break (Shelf), inside the Amundsen Sea polynya and in open waters adjacent to the
Dotson glacier (Dotson) during a Phaeocystis antarctica bloom in 2010-2011. Panels at top of each graph denote the relative contribution of a taxon within each dataset; the " $\star$ " symbols denote deep (>350 m) samples. Oligotypes detected at low abundance $(n<200)$ in the dataset were removed from the analysis. 


\section{FREE LIVING vs. PARTICLE ASSOCIATED BACTERIAL TAXA}

During the 2007/2008 bloom event in the Amundsen polynya samples from the surface (above $100 \mathrm{~m}$ depth, $n=4$ ) and at $250 \mathrm{~m}$ depth $(n=1)$ were size fractionated. The size fractionation differentiated between bacteria in the $0.2-3 \mu \mathrm{m}(<3-\mu \mathrm{m})$ and $3-$ $200 \mu \mathrm{m}(>3-\mu \mathrm{m})$ fractions. The $<3-\mu \mathrm{m}$ fraction was thought to be enriched with V6 reads from free-living bacteria, whereas V6 reads in the $>3-\mu \mathrm{m}$ fraction were derived from particleassociated bacteria. The most common particles were Phaeocystis solitary cells and colonies along with diatom species that together gave rise to the intense phytoplankton bloom. We observed a substantial increase of $P$. antarctica (from $25 \pm 17.1$ to $51.2 \pm 24.3 \%$ of total V6 reads) and a much less pronounced increase in diatom V6 reads (from $1.7 \pm 0.8$ to $9.5 \pm 4 \%$ ) in the $>3-\mu \mathrm{m}$ fraction of the polynya surface. Presumably, $P$. antarctica was present as single cells in the $<3-\mu \mathrm{m}$ fraction and as small-medium sized colonies in the $>3-\mu \mathrm{m}$ fraction. A taxon-by-taxon comparison of bacterial genotypes between the two size fractions in the surface mixed layer of the polynya identified several taxa that showed a higher relative abundance in either $<3-\mu \mathrm{m}$ or $>3-\mu \mathrm{m}$ fractions (Figures 6A-C). For each taxon we calculated the relative enrichment as the ratio of their abundance in the two size fractions using the following equation:

$$
\left(\frac{2 \mathrm{X}(>3 \mu \mathrm{m} \text { fraction })}{<3 \mu \mathrm{m} \text { fraction }+>3 \mu \mathrm{m} \text { fraction }}-1\right)
$$

A PCA showed that a large majority of dominant taxa were enriched in the small fraction (Figure S4). SAR92 reads were abundant in each fraction but this genus was significantly enriched in the $>3-\mu \mathrm{m}$ fraction. Whereas they contributed $\sim 13 \%$ of the $\mathrm{V} 6$ reads in the $<3-\mu \mathrm{m}$ fraction their contribution rose to $>35 \%$ in the $>3-\mu \mathrm{m}$ fraction (Figures $6 \mathbf{A}, \mathbf{B}$ ). Thus, the enrichment ratio of SAR92 (Gammaproteobacteria) was close to 0.5 (Figure 6C). Similarly, Oceanospirillum-like (Gammaproteobacteria) genotypes were abundant in both the $<3-\mu \mathrm{m}$ and $>3-\mu \mathrm{m}$ fractions, but their enrichment was less pronounced (Figure 6C). Several low abundance taxa a single Firmicute, Tepidanaerobacter, and Bacteroidetes genotypes identified as Haliscomenobacter, Lutibacter, Ulvibacter, and Cryomorphaceae showed the same trend as was observed for SAR92 and they were enriched in the $>3-\mu \mathrm{m}$ fraction (Figure 6C). In contrast, different Flavobacteria, Oceanospirillales, and Piscirickettsiaceae (Gammaproteobacteria), and Pelagibacter (Alphaproteobacteria) together with the low abundance taxa Acetivibrio (Firmicutes) and SAR324 (Deltaproteobacteria), dominated in the $<3-\mu \mathrm{m}$ fraction and they were presumably present mostly as free-living cells (Figures 6A-C).

A similar picture of an association of certain bacterial taxa with Phaeocystis particles emerged from a further analysis of the $2010 / 2011$ bloom event in the ASP. We observed a significant correlation $\left(R^{2}=0.75, p=9.5 \mathrm{e}-8\right)$ between the relative abundances of $P$. antarctica and those of SAR92 across 23 datasets (Figure 6D). Note that relative abundances of SAR92 were normalized to the
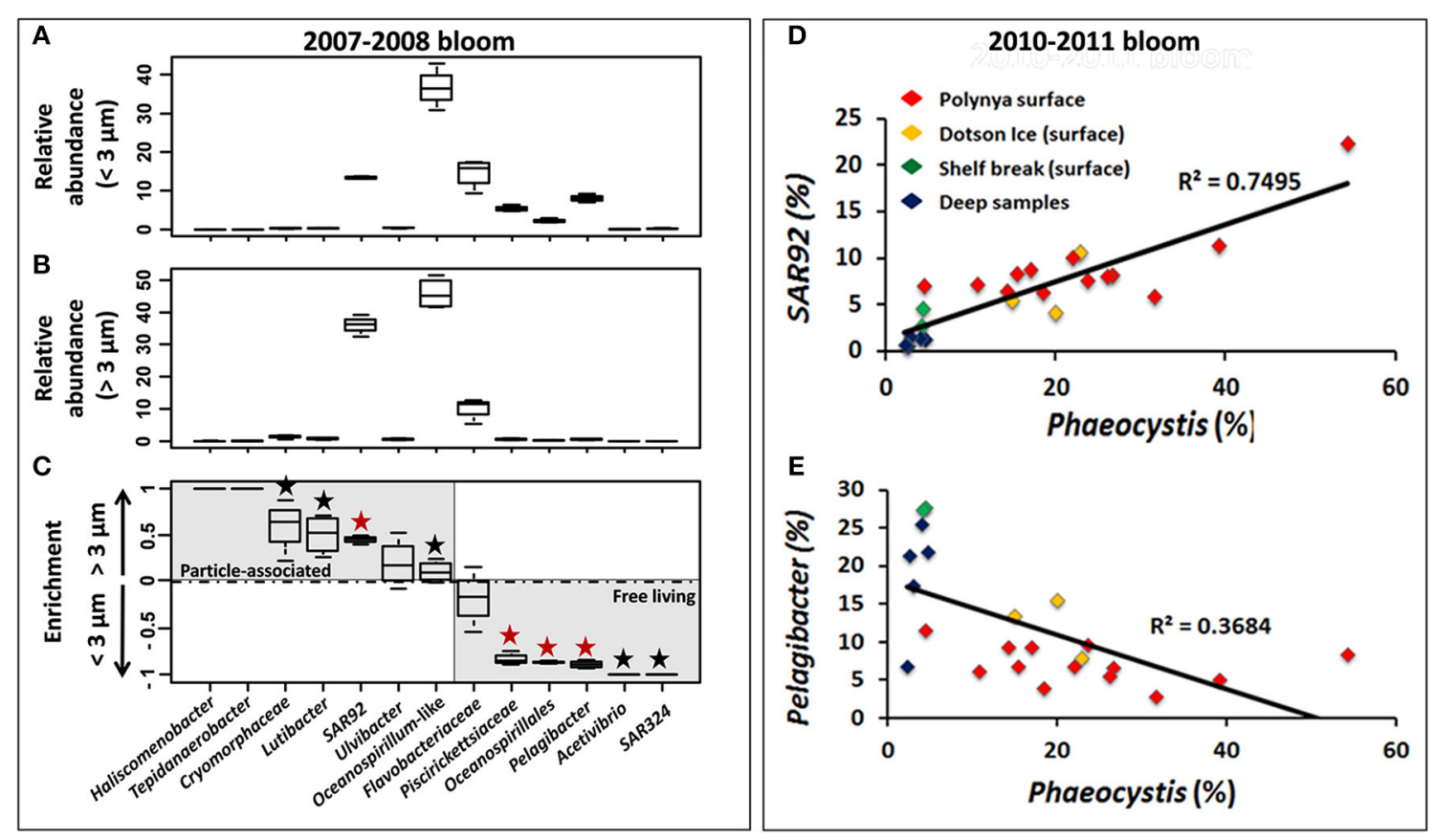

FIGURE 6 | Relative abundance of 13 bacterial taxa in the $<3 \mu \mathrm{m}$ (A) and $>3 \mu \mathrm{m}$ (B) size fractions and preferential enrichment (C) of these taxa in either fraction among Phaeocystis bloom samples from surface waters in the Amundsen Sea polynya in 2007-2008. ANOVA test was performed using STAMP software to test the significance of their enrichment in the two size fractions. For each taxa, a black " $\star$ " symbol was added when $p$-value score was lower than 0.05 (>95\% confidence level). This symbol displayed in red indicates a $p<0.01$ (>99\% confidence level). Correlation between Phaeocystis genotypes (percentage of the whole community) and SAR92 (D) or Pelagibacter (E) (percentage of the bacterial community) are displayed across all datasets during the Phaeocystis bloom of 2010-2011. 
number of bacterial reads in each sample whereas relative abundances of Phaeocystis were normalized to total reads (bacteria + chloroplast reads). Assuming a single 16S rRNA gene copy per SAR92 genome (as detected in SAR92 HTCC2207) and the presence of two chloroplasts per alga cell (Moisan et al., 2006), each with two single 16S rRNA gene copy (as detected in the chloroplast genome of $P$. antarctica strain CCMP1374) we estimate an approximate 2:1 occurrence of SAR92 per Phaeocystis cell. On the other hand, Pelagibacter V6 reads, which were more abundant in the $<3-\mu \mathrm{m}$ fraction (Figure 6C), showed a trend of decrease (while not significant) with increasing abundance of Phaeocystis (Figure 6E), thereby independently confirming the observations made for the 2007/2008 bloom event.

In contrast to their relative abundances in the surface samples, diatoms were more enriched in the $>3-\mu \mathrm{m}$ fraction of the deep sample taken during the 2007/2008 bloom (from 0.8 to $56.6 \%$ of the total V6) than $P$. antarctica (from 7 to $21.8 \%$ ) (data not shown). V6 reads for taxa such as Pelagibacter, Oceanospirillales and Piscirickettsiaceae were still more abundant in the $<3$ $\mu \mathrm{m}$ fraction. However, strong shifts in taxonomic make-up of the $>3-\mu \mathrm{m}$ fraction as compared to the $<3-\mu \mathrm{m}$ fraction occurred (Figure 7). SAR92 V6 reads were not enriched in the $>3-\mu \mathrm{m}$ fraction of the sample taken from below the surface mixed layer. Although by no means significant, its relative abundance was slightly higher in the $<3-\mu \mathrm{m}$ fraction $(+3.2 \%$ of the bacterial community). However, in addition to the omnipresent Cryomorphaceae and Ulvibacter other taxa became more enriched in the $>3 \mu \mathrm{m}$ fraction. In particular we identified Colwellia, Pseudoalteromonas and Cerasicoccus genotypes that were associated with decaying Phaeocystis and/or diatoms, the dominant type of particles in samples below the surface mixed layer. The relative enrichment of these taxa in the $>3-\mu \mathrm{m}$ fraction [as compared to the $<3-\mu \mathrm{m}$ fraction, see Equation (1)] was by a ratio of 0.96
(Colwellia), 0.90 (Pseudoalteromonas) and 0.98 (Cerasicoccus). These relative enrichments were much less pronounced in surface samples with ratios of $0( \pm 0.09), 0.24( \pm 0.35)$, and $0.12( \pm 0.38)$ respectively.

\section{DISCUSSION}

Whereas persistent blooms of Phaeocystis antarctica have been reported for multiple Antarctic polynyas (Arrigo et al., 1999; Smith et al., 2000; Arrigo and Van Dijken, 2003; Alderkamp et al., 2012; Yager et al., 2012) and even in the ACC proper (Alderkamp and van Dijken, pers. comm.), we do not understand all the factors that drive bloom formation and/or support bloom longevity. Previous studies have focused on Fe-limitation of such blooms (Mills et al., 2012) and the role of Fe-supply from glacier melts to polynya surface waters (Alderkamp et al., 2012). Other studies addressed the role of Phaeocystis colony formation and control of colony size by grazer populations (Tang et al., 2008). Here we studied the potential for the bacterial flora to play a role in the bloom biology of $P$. antarctica. We have obtained the deepest sequencing of the ASP to date: $10^{5}-10^{6}$ paired-end (100\% overlap) reads for the V6 hypervariable region of $16 \mathrm{~S}$ rRNA per sample as compared to other studies that report $10^{3}-10^{4}$ reads for $\mathrm{V} 1$ and $\mathrm{V} 3-\mathrm{V} 4$ obtained by pyrosequencing (Kim et al., 2013; Dinasquet et al., submitted; Richert et al., submitted). The complete overlapping sequencing strategy performed here enhanced sequence quality for each V6 read, and so provided highly reliable signatures for the detection of low abundance bacterial populations. Also, using oligotyping we avoided the commonly-used 97\% similarity cut-off and partitioned our dataset into homogeneous genotypic units that entail minimal phylogenetic mixture. The single-nucleotide resolution oligotyping achieves allowed us to determine various geographic patterns of bacterial and algal community structure within the confines
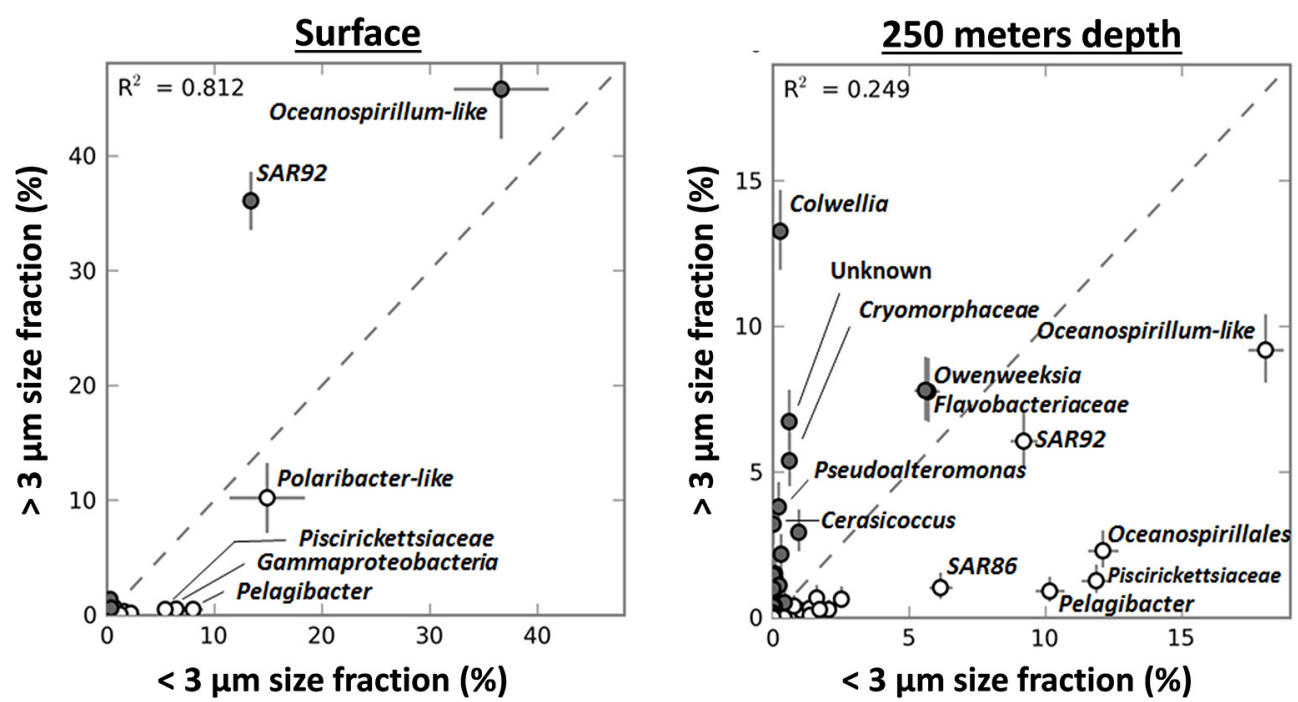

FIGURE 7 | The relative distribution in percentage of genera (based on GAST classification and using STAMP software) in the $<3 \mu \mathrm{m}$ and $>3 \mu \mathrm{m}$ size fractions in samples from surface layers $(n=8)$ and from $250 \mathrm{~m}$ depth $(n=2)$ during the

Phaeocystis bloom in 2007-2008. The coloring of circles reflects the enrichment of the taxa (closed circles when more abundant in the $>3 \mu \mathrm{m}$ size fraction, open circles when more abundant in the $<3 \mu \mathrm{m}$ size fraction). 
of this isolated ecosystem. These patterns suggest different niche adaptations. As commonly observed along vertical profiles, depth played a major role in the partitioning of microbial taxa. E.g., diversity of Nitrospina genotypes was distinctly different in the deep samples of the shelf break area than elsewhere in the ASP. Oligotyping was also instrumental in identifying partitioning genotype diversity along horizontal gradients, e.g., in determining the diversity of diatom populations (Figure 4). These patterns suggest an abundance of niche adaptations for which selective forces and ecological implications are yet to be determined. The main observations from this study are: (1) P. antarctica blooms are accompanied by a unique and stable community of free-living bacteria over extended time scales and (2) Phaeocystis cells and colonies associate with selected bacterial taxa. We have identified taxa (e.g., SAR92) that accompany productive Phaeocystis populations in surface water and different taxa (e.g., Colwellia) that are associated with-supposedly decaying-populations of Phaeocystis cells at depth, below the illuminated, surface mixed layer.

Antarctic phytoplankton populations under non-bloom conditions typically include $P$. antarctica as one of the dominant species (Yager et al., 2012). Such populations in the ACC, or in coastal waters near the Antarctic Peninsula are accompanied by bacterial populations that are dominated by Proteobacteria, mostly Pelagibacter and SAR11-like genotypes (West et al., 2008; Brown et al., 2012; Wilkins et al., 2013a, this study). During bloom events $P$. antarctica often becomes the dominant phytoplankter, most notably in the ASP where such blooms recur annually (Arrigo et al., 1999; Smith et al., 2000; Arrigo and Van Dijken, 2003; Alderkamp et al., 2012; Yager et al., 2012; Kim et al., 2013; Dinasquet et al., submitted). Based on different proxies it has been estimated that the P. antarctica blooms contribute $>99 \%$ of chlorophyll $a$, biomass or cell count. We found that $>78 \%$ of the V6 reads for chloroplasts (a proxy for relative abundance of Phaeocystis cells) were contributed by $P$. antarctica in the $<20$ $\mu \mathrm{m}$ fraction of polynya samples. Based on chloroplast $16 \mathrm{~S}-\mathrm{V} 6$ we found that the bloom was dominated by a single oligotype. In adjacent waters we discovered a shift in oligotype abundances suggesting that several Phaeocystis genotypes did not contribute to the bloom formation in the ASP but had a distinct presence in the waters abutting the polynya.

Since the bulk of the $P$. antarctica bloom was contained in colonies $>20-\mu \mathrm{m}$ this percentage is expected to exceed $78 \%$ of the whole phytoplankton community. Whether it is by food web interactions, decay of dead Phaeocystis cells, viral lysis, or simple secretion of dissolved organic compounds, Phaeocystis blooms can have a large impact on heterotrophic activities and hence shape bacterial communities. We found that members of the Bacteroidetes were most abundant in Phaeocystis dominated samples. These observations are in agreement with investigations performed in other locations of the Southern Ocean (Wilkins et al., 2013a; Williams et al., 2013) and support the general standing of this phylum in the specialization of high molecular weight organic matter degradation (Thomas et al., 2011). Members of the Bacteroidetes and Proteobacteria made up 95$97 \%$ of the microbial community in the ASP bloom samples. SAR92, Oceanospirillum-like, and Pelagibacter (Proteobateria), along with Polaribacter sensu lato (Bacteroidetes) combined were $73.1 \%( \pm 5.7)$ of the bacterial community during the 3 weeks covered by the 2010-2011 cruise. The relative abundances of these taxa are similar to those reported by Kim et al. (2013) for the later stages of the ASP Phaeocystis bloom (January-February 2010). In addition, these same taxa dominated the Phaeocystis bloom at our sampling site during the summer of 2007-2008. Based on the findings above we suggest that $P$. antarctica blooms are accompanied by stable and distinct microbial communities. Within this community we detected a single, dominant oligotype ( $>80 \%$ of the V6 reads) for each of the dominant taxa (e.g., SAR92, Oceanospirillum-like), in contrast with the multiplicity of oligotypes for taxa known from other niches (e.g., SAR86, Nitrospina). This observation suggests that specialized ecotypes with conserved genotype signatures co-exist (and possibly interact) with $P$. antarctica. Different phytoplankton species produce different DOM compounds, but closely related species have very similar DOM spectra (Becker et al., 2014). Consistent with this result, blooms of different Phaeocystis species have very similar bacterial communities associated with them (Alderkamp et al., 2007) and these bacteria readily degrade labile, presumably low molecular weight carbohydrates produced by these algae (Osinga et al., 1997; Smith et al., 1998; Janse et al., 1999). In addition, polymers excreted by Phaeocystis blooms provide a nitrogen rich substrate for heterotrophic bacteria (Solomon et al., 2003) and are expected to induce shifts in microbial community structure. In our study we observed that SAR86 oligotypes (Figure 5) associated with Phaeocystis blooms were distinct from other SAR86 in adjacent waters with diverse diatom populations as well as in the underlying deep waters. Controlled experimental manipulations and genomic analyses of bacterial metabolisms are needed to better understand the interactions between alga and bacteria and their effects on bacterial community structure.

Biomass produced by Phaeocystis blooms is rapidly exported to deeper waters, where cells and colonies become senescent (Ditullio et al., 2000). During the bloom in the ASP in 2010 we detected Phaeocystis biomass trapped beneath the surface mixed layer that provides a substrate for microbial degradation. This senescent part of the population was accompanied by a very different microbial community. Contributions by SAR92, Flavobacteriaceae and Oceanospirillum-like genotypes were diminished whereas the Gammaproteobacterium SAR86, Nitrospina and diverse members of the Verrucomicrobia had become the dominant taxa. The shift in microbial community composition toward Verrucomicrobia and Gammaproteobacteria has been reported for senescent Phaeocystis populations (Alderkamp et al., 2007). The increased contribution of Nitrospina at depth is likely a result of its role in nitrate formation from ammonium (Luecker et al., 2013) released during the decomposition of senescent Phaeocystis populations.

During bloom situations Phaeocystis is mostly found as large colonies protected by a semi-permeable membrane (see Schoemann et al., 2005, for a review). In early studies these colonies were thought of as cells within a mucopolysaccharide matrix, but this has been revised to a model where an outer membrane encloses Phaeocystis cells within a liquid matrix (Hamm et al., 1999). Indeed, microscopic inspection of $P$. antarctica 
colonies showed free-moving and rapidly swimming ciliates within the colony matrix (Delmont, unpublished data). Because of its virtually monotypic blooms and the large cells/colony size $P$. antarctica can be readily enriched by size fractionation. We showed that $>3-\mu \mathrm{m}$ fractions are significantly enriched with the Gammaproteobacteria SAR92. A preliminary estimate indicates that SAR92 and P. antarctica cells in surface bloom samples occur in approximately a 2:1 ratio. SAR92 is typically limited by carbon availability and despite carrying proteorhodopsin it does have a photoheterotrophic lifestyle (Stingl et al., 2007). A close association of SAR92 and P. antarctica (with SAR92 possibly contained within the colony liquid matrix) could thus be of mutual benefit. Preliminary findings from a metagenome analysis of the 20102011 ASP bloom event indicates that SAR92 and other Phaeocystis associated bacterial taxa may play a role in sulfur metabolism and iron acquisition via ferrochelatase and siderophore production (Delmont et al., in prep.). SAR92 was abundantly present in phytoplankton bloom samples following a natural occurrence of iron-enrichment in the Southern Ocean (West et al., 2008). This would be especially beneficial if $P$. antarctica would harbor SAR92 within its colony matrix. The fact that this matrix resembles an enclosed aqueous environment allows for rapid diffusion of these secreted compounds and hence efficient usage.

We propose that a mutualistic relationship between Phaeocystis and associated bacteria underpins the intensity and longevity of its blooms and thereby sequester substantial amounts of atmospheric carbon dioxide in high-latitude oceans (Smith et al., 1991). Determining the genomic content and activity of associated bacteria will help understanding these mechanisms. Conversely, we determined that a bacterial community dominated by members of the genus Colwellia was associated with supposedly senescent Phaeocystis cells at depth. Such Colwellia are known for the production of extracellular polysaccharides/enzyme complexes involved in the breakdown of highmolecular-weight organic compounds (Methé et al., 2005). Therefore, Colwellia and related taxa may play an important role in the recycling of carbon, sulfur and nitrogen by rapidly degrading bloom biomass before their complete sedimentation, a process that can last for more than 8 months (Kirchman et al., 2001b).

\section{ACKNOWLEDGMENTS}

This work received financial support from NSF Antarctic Sciences awards ANT-1142095 (Anton F. Post), ANT-0839069 and ANT-0741409 (Patricia L. Yager), and ANT-0839012 (Hugh W. Ducklow). We further acknowledge the support by "Oden Southern Ocean," SWEDARP 2010/2011, a project organized by the Swedish Polar Research Secretariat and National Science Foundation Office of Polar Programs. We are indebted to the Nathaniel B Palmer crew and the Raytheon science crew for their assistance during sampling across the ASP. Drs. Kevin Arrigo and Anne Carlijn Alderkamp (Stanford University) contributed to the maps of the Amundsen Sea shown in Figure 1. The 2007/2008 samples were collected with the assistance of K. Bakker and sequenced as part of the International Census of Marine Microbes (ICOMM).We gratefully acknowledge technical assistance provided by A. Murat Eren, Sharon Grim and Joseph H. Vineis during various steps of the sequencing and quality control analyses. We are also grateful to Sara Paver for critical comments and to the reviewers for their constructive remarks.

\section{SUPPLEMENTARY MATERIAL}

The Supplementary Material for this article can be found online at: http://www.frontiersin.org/journal/10.3389/fmicb. 2014.00646/abstract

Table S1 | Sample designations, metadata and parameters relating to the 16S-V6 sequence datasets used in the analysis underlying Figure 2. Sequence data originated from three different projects and they are publically available on the VAMPS website (http://vamps.mbl.edu/).

Table S2 | Sample designations and environmental metadata relating to the ASPIRE cruise (2010-2011 bloom event).

Figure S1 | Heat map (Bray-Curtis distance) based on the relative distribution of bacterial taxa (based on GAST classification at the genus level) in $3 \times 4$ samples collected from the Antarctic Circumpolar Current, off the Antarctica peninsula and inside the Amundsen Sea polynya. Dissimilarity between samples is reflected by a color gradient ranging from red (high dissimilarity) to blue (low dissimilarity).

Figure S2 | Correspondence analysis (COA, euclidean distance) of the relative distribution of major bacterial taxa across high throughput sequencing datasets from the Antarctic Circumpolar Current, off the Antarctic Peninsula and the Amundsen Sea polynya. The latter includes surface and deep bacterial communities sampled at the outer rim of the polynya, near the Dotson Glacier and in the open waters of the polynya. Note that the "polynya deep" label is partly covering the "Dotson Glacier deep" label. Pyrosequencing datasets of the Amundsen Sea polynya representing the 0.2-3 $\mu \mathrm{m}$ size fraction sampled during the 2007-2008 bloom event (4 surface and 3 deep samples; see Table S1) were included in the analysis.

Figure S3 | (A) represents the number of bacterial species identified in each V6 data from the 2010-2011 bloom event using the Global Assignment of Sequence Taxonomy (GAST) pipeline (Huse et al., 2008) and the SILVA 111 database for reference (Quast et al., 2013). (B) represents the number of reads generated for each data set. Datasets represent surface $(n=18)$ and deep samples $(n=5)$.

Figure S4 | Principal component analysis (PCA) of the relative abundance of major bacterial taxa (based on GAST classification) in the $<3 \mu \mathrm{m}$ (A) and $>3 \mu \mathrm{m}$ (B) size fractions of surface and deep samples of the Amundsen polynya during a Phaeocystis bloom in 2007-2008 by comparing free living bacteria $(0.2-3-\mu \mathrm{m}$ size fraction, $n=4)$ and alga/particulate associated bacteria ( $>3-\mu \mathrm{m}$ size fraction, $n=4)$.

\section{REFERENCES}

Alderkamp, A.-C., Buma, A. G., and Van Rijssel, M. (2007). The carbohydrates of Phaeocystis and their degradation in the microbial food web. Biogeochemistry 83, 99-118. doi: 10.1007/s10533-007-9078-2

Alderkamp, A. C., Mills, M. M., Van Dijken, G. L., Laan, P., Thuróczy, C. E., Gerringa, L. J., et al. (2012). Iron from melting glaciers fuels phytoplankton blooms in the Amundsen Sea (Southern Ocean): phytoplankton characteristics and productivity. Deep Sea Res. II 71, 32-48. doi: 10.1016/j.dsr2.2012.03.005

Arrigo, K. R., Robinson, D. H., Worthen, D. L., Dunbar, R. B., Ditullio, G. R., Vanwoert, M., et al. (1999). Phytoplankton community structure and the drawdown of nutrients and $\mathrm{CO}_{2}$ in the Southern Ocean. Science 283, 365-367. doi: 10.1126/science.283.5400.365

Arrigo, K. R., and Van Dijken, G. L. (2003). Phytoplankton dynamics within 37 Antarctic coastal polynya systems. J. Geophys. Res. 108, 1-18. doi: 10.1029/2002JC001739 
Arrigo, K. R., Worthen, D., Schnell, A., and Lizotte, M. P. (1998). Primary production in Southern Ocean waters. J. Geophys. Res. Oceans (1978-2012) 103, 15587-15600. doi: 10.1029/98JC00930

Becker, J. W., Berube, P. M., Follett, C. L., Waterbury, J. B., Chisholm, S. W., Delong, E. F., et al. (2014). Closely related phytoplankton species produce similar suites of dissolved organic matter. Front. Microbiol. 5:111. doi: 10.3389/fmicb.2014.00111

Behrenfeld, M. J., and Boss, E. S. (2014). Resurrecting the ecological underpinnings of ocean plankton blooms. Annu. Rev. Mar. Sci. 6, 16.11-16.28. doi: 10.1146/annurev-marine-052913-021325

Bertrand, E. M., Saito, M. A., Jeon, Y. J., and Neilan, B. A. (2011b). Vitamin B biosynthesis gene diversity in the Ross Sea: the identification of a new group of putative polar B B biosynthesizers. Environ. Microbiol. 13, 1285-1298. doi: 10.1111/j.1462-2920.2011.02428.x

Bertrand, E. M., Saito, M. A., Lee, P. A., Dunbar, R. B., Sedwick, P. N., and Ditullio, G. R. (2011a). Iron limitation of a springtime bacterial and phytoplankton community in the Ross Sea: implications for vitamin $\mathrm{B}_{12}$ nutrition. Front. Microbiol. 2:160. doi: 10.3389/fmicb.2011.00160

Brown, M. V., Lauro, F. M., Demaere, M. Z., Muir, L., Wilkins, D., Thomas, T., et al. (2012). Global biogeography of SAR11 marine bacteria. Mol. Syst. Biol. 8, 1-13. doi: $10.1038 / \mathrm{msb} .2012 .28$

Capone, D. G., Burns, J. A., Montoya, J. P., Subramaniam, A., Mahaffey, C., Gunderson, T., et al. (2005). Nitrogen fixation by Trichodesmium spp.: an important source of new nitrogen to the tropical and subtropical North Atlantic Ocean. Global Biogeochem. Cycles 19:GB2024. doi: 10.1029/2004 GB002331

Capone, D. G., Zehr, J. P., Paerl, H. W., Bergman, B., and Carpenter, E. J. (1997). Trichodesmium, a globally significant marine cyanobacterium. Science 276, 1221-1229. doi: 10.1126/science.276.5316.1221

Carlson, C. A., Ducklow, H. W., and Hansel, D. A. (1998). Organic carbon partitioning during spring phytoplankton blooms in the Ross Sea polynya and the Sargasso Sea. Oceanography 43, 375-386.

Chen, J. F., Xu, N., Jiang, T. J., Wang, Y., Wang, Z. H., and Qi, Y. Z. (1999). A report of Phaeocystis globosa bloom in coastal water of Southeast China. J. Jinan Univ. Nat. Sci. Med. Ed. 20, 124-129.

Cole, J. J. (1982). Interactions between bacteria and algae in aquatic ecosystems. Annu. Rev. Ecol. Syst. 13, 291-314. doi: 10.1146/annurev.es.13.110182.001451

Croft, M. T., Lawrence, A. D., Raux-Deery, E., Warren, M. J., and Smith, A. G. (2005). Algae acquire vitamin $B_{12}$ through a symbiotic relationship with bacteria. Nature 438, 90-93. doi: 10.1038/nature04056

Ditullio, G., Grebmeier, J., Arrigo, K., Lizotte, M., Robinson, D., Leventer, A., et al. (2000). Rapid and early export of Phaeocystis antarctica blooms in the Ross Sea, Antarctica. Nature 404, 595-598. doi: 10.1038/35007061

Doucette, G. J. (1995). Interactions between bacteria and harmful algae: a review. Nat. Toxins 3, 65-74. doi: 10.1002/nt.2620030202

Ducklow, H. W. (2003). Seasonal production and bacterial utilization of DOC in the Ross Sea, Antarctica. Antarct. Res. Ser. 78, 143-157. doi: 10.1029/ 078ARS09

Eren, A. M., Maignien, L., Sul, W.-J., Murphy, L. G., Grim, S. L., Morrison, H. G., et al. (2013a). Oligotyping: differentiating between closely related microbial taxa using 16S rRNA gene data. Methods Ecol. Evol. 4, 1111-1119. doi: 10.1111/2041210X.12114

Eren, A. M., Vineis, J. H., Morrison, H. G., and Sogin, M. L. (2013b). A filtering method to generate high quality short reads using Illumina paired-end technology. PLoS ONE 8:e66643. doi: 10.1371/journal.pone.0066643

Freitas, S., Hatosy, S., Fuhrman, J. A., Huse, S. M., Welch, D. B. M., Sogin, M. L., et al. (2012). Global distribution and diversity of marine Verrucomicrobia. ISME J. 6, 1499-1505. doi: 10.1038/ismej.2012.3

Ghiglione, J.-F., Galand, P. E., Pommier, T., Pedros-Alio, C., Maas, E. W., Bakker, K., et al. (2012). Pole-to-pole biogeography of surface and deep marine bacterial communities. Proc. Natl. Acad. Sci. U.S.A. 109, 17633-17638. doi: 10.1073/pnas. 1208160109

Grzymski, J. J., Riesenfeld, C. S., Williams, T. J., Dussaq, A. M., Ducklow, H., Erickson, M., et al. (2012). A metagenomic assessment of winter and summer bacterioplankton from Antarctica Peninsula coastal surface waters. ISME J. 6 , 1901-1915. doi: 10.1038/ismej.2012.31

Hamm, C. E., Simson, D. A., Merkel, R., and Smetacek, V. (1999). Colonies of Phaeocystis globosa are protected by a thin but tough skin. Mar. Ecol. Prog. Ser. 187, 101-111. doi: 10.3354/meps187101
Hmelo, L. R., Van Mooy, B. A. S., and Mincer, T. J. (2012). Characterization of bacterial epibionts on the cyanobacterium Trichodesmium. Aquat. Microb. Ecol. 67, 1-14.

Huse, S. M., Dethlefsen, L., Huber, J. A., Welch, D. M., Relman, D. A., and Sogin, M. L. (2008). Exploring microbial diversity and taxonomy using SSU rRNA hypervariable tag sequencing. PLoS Genet. 4:e1000255. doi: 10.1371/journal.pgen. 1000255

Huse, S. M., Huber, J. A., Morrison, H. G., Sogin, M. L., and Welch, D. M. (2007). Accuracy and quality of massively parallel DNA pyrosequencing. Genome Biol. 8:R143. doi: 10.1186/gb-2007-8-7-r143

Janse, I., Van Rijssel, M., Ottema, A., and Gottschal, J. C. (1999). Microbial breakdown of Phaeocystis mucopolysaccharides. Limnol. Oceanogr. 44, 1447-1457. doi: 10.4319/lo.1999.44.6.1447

Kim, J.-G., Park, S.-J., Cha, I.-T., Kim, K.-H., Yang, E.-J., Kim, Y.-N., et al. (2013). Unveiling abundance and distrbituion of planktonic Bacteria and Archaea in a polynya in Amundsen Sea, Antarctica. Environ. Microbiol. 16, 1566-1578. doi: $10.1111 / 1462-2920.12287$

Kirchman, D. L., Meon, B., Ducklow, H. W., Carlson, C. A., Hansell, D. A., and Steward, G. F. (2001a). Glucose fluxes and concentrations of dissolved combined neutral sugars (polysaccharides) in the Ross Sea and Polar Front Zone, Antarctica. Deep Sea Res. II 48, 4179-4197. doi: 10.1016/S0967-0645(01) 00085-6

Kirchman, D. L., Meon, B., Ducklow, H. W., Carlson, C. A., Hansell, D. A., and Steward, G. F. (2001b). Glucose fluxes and concentrations of dissolved combined neutral sugars (polysaccharides) in the Ross Sea and Polar Front Zone, Antarctica. Deep Sea Res. II 48, 4179-4197. doi: 10.1016/S0967-0645(01) 00085-6

Luecker, S., Nowka, B., Rattei, T., Spieck, E., and Daims, H. (2013). The genome of Nitrospina gracilis illuminates the metabolism and evolution of the major marine nitrite oxidizer. Front. Microbiol. 4:27. doi: 10.3389/fmicb.2013.00027

Martin, J. H., Fitzwater, S. E., and Gordon, R. M. (1990). Iron deficiency limits phytoplankton growth in Antarctic waters. Global Biogeochem. Cycles 4, 5-12. doi: 10.1029/GB004i001p00005

Methé, B. A., Nelson, K. E., Deming, J. W., Momen, B., Melamud, E., Zhang, X., et al. (2005). The psychrophilic lifestyle as revealed by the genome sequence of Colwellia psychrerythraea $34 \mathrm{H}$ through genomic and proteomic analyses. Proc. Natl. Acad. Sci. U.S.A. 102, 10913-10918. doi: 10.1073/pnas.0504766102

Mills, M. M., Alderkamp, A. C., Thuróczy, C. E., Van Dijken, G. L., Laan, P., De Baar, H. J., et al. (2012). Phytoplankton biomass and pigment responses to $\mathrm{Fe}$ amendments in the Pine Island and Amundsen polynyas. Deep Sea Res. II 71, 61-76. doi: 10.1016/j.dsr2.2012.03.008

Moisan, T. A., Ellisman, M. H., Buitenhuys, C. W., and Sosinsky, G. E. (2006). Differences in chloroplast ultrastructure of Phaeocystis antarctica in low and high light. Mar. Biol. 149, 1281-1290. doi: 10.1007/s00227-006-0321-5

Osinga, R., De Vries, K. A., Lewis, W. E., Van Raaphorst, W., Dijkhuizen, L., and Van Duyl, F. C. (1997). Aerobic degra-dation of phytoplankton debris dominated by Phaeocystis sp. in different physiological stages of growth. Aquat. Microb. Ecol. 12, 11-19. doi: 10.3354/ame012011

Parks, D. H., and Beiko, R. G. (2010). Identifying biologically relevant differences between metagenomic communities. Bioinformatics 26, 715-721. doi: 10.1093/bioinformatics/btq041

Piquet, A. M., Bolhuis, H., Meredith, M. P., and Buma, A. G. (2011). Shifts in coastal Antarctic marine microbial communities during and after melt water-related surface stratification. FEMS Microbiol. Ecol. 76, 413-427. doi: 10.1111/j.15746941.2011.01062.x

Quaiser, A., López-García, P., Zivanovic, Y., Henn, M. R., Rodriguez-Valera, F., and Moreira, D. (2008). Comparative analysis of genome fragments of Acidobacteria from deep Mediterranean plankton. Environ. Microbiol. 10, 2704-2717. doi: 10.1111/j.1462-2920.2008.01691.x

Quast, C., Pruesse, E., Yilmaz, P., Gerken, J., Schweer, T., Yarza, P., et al. (2013). The SILVA ribosomal RNA gene database project: improved data processing and web-based tools. Nucleic Acids Res. 41, D590-D596. doi: 10.1093/nar/gks1219

Rousseau, V., Becquevort, S., Parent, J. Y., Gasparini, S., Daro, M. H., Tackx, M., et al. (2000). Trophic efficiency of the planktonic food web in a coastal ecosystem dominated by Phaeocystis colonies. J. Sea Res. 43, 357-372. doi: 10.1016/S13851101(00)00018-6

Schoemann, V., Becquevort, S., Stefels, J., Rousseau, V., and Lancelot, C. (2005). Phaeocystis blooms in the global ocean and their controlling mechanisms: a review. J. Sea Res. 53, 43-66. doi: 10.1016/j.seares.2004.01.008 
Seymour, J. R., Simo, R., Ahmed, T., and Stocker, R. (2010). Chemoattraction to dimethylsulfoniopropionate throughout the marine microbial food web. Science 329, 342-345. doi: 10.1126/science.1188418

Sher, D., Thompson, J. W., Kashtan, N., Croal, L., and Chisholm, S. W. (2011). Response of Prochlorococcus ecotypes to co-culture with diverse marine bacteria. ISME J. 5, 1125-1132. doi: 10.1038/ismej.2011.1

Sinigalliano, C. D., Gidley, M., Shibata, T., Whitman, D., Dixon, T., Laws, E., et al. (2007). Impacts of Hurricanes Katrina and Rita on the microbial landscape of the New Orleans area. Proc. Natl. Acad. Sci. U.S.A. 104, 9029-9034. doi: 10.1073/pnas.0610552104

Smith, W. O., Jr., Carlson, C. A., Ducklow, H. W., and Hansell, D. A. (1998). Growth dynamics of Phaeocystis antarctica-dominated plankton assemblages from the Ross Sea. Mar. Ecol. Prog. Ser. 168, 229-244. doi: 10.3354/meps168229

Smith, W. O. Jr, Codispoti, L. A., Nelson, D. M., Manley, T., Buskey, E. J., Niebauer, H. J., et al. (1991). Importance of Phaeocystis blooms in the high-latitude ocean carbon cycle. Nature 352, 514-516.

Smith, W. O. Jr., Dennett, M. R., Mathot, S., and Caron, D. A. (2003). The temporal dynamics of the flagellated and colonial stages of Phaeocystis antarctica in the Ross Sea. Deep Sea Res. II 50, 605-617. doi: 10.1016/S0967-0645(02)00586-6

Smith, W. O. Jr., Marra, J., Hiscock, M. R., and Barber, R. T. (2000). The seasonal cycle of phytoplankton biomass and primary productivity in the Ross Sea, Antarctica. Deep-Sea Res. II 47, 3119-3140. doi: 10.1016/S0967-0645(00) 00061-8

Sogin, M. L., Morrison, H. G., Huber, J. A., Welch, D. M., Huse, S. M., Neal, P. R., et al. (2006). Microbial diversity in the deep sea and the underexplored "rare biosphere. Proc. Natl. Acad. Sci. U.S.A. 103, 12115-12120. doi: 10.1073/pnas.0605127103

Solomon, C. M., Lessard, E. J., Keil, R. G., and Foy, M. S. (2003). Characterization of extracellular polymers of Phaeocystis globosa and P. antarctica. Mar. Ecol. Prog. Ser. 250, 81-89. doi: 10.3354/meps 250081

Stingl, U., Desiderio, R. A., Cho, J.-C., Vergin, K. L., and Giovannoni, S. J. (2007). The SAR92 clade: an abundant coastal clade of culturable marine bacteria possessing proteorhodopsin. Appl. Environ. Microbiol. 73, 2290-2296. doi: 10.1128/AEM.02559-06

Stocker, R., and Seymour, J. R. (2012). Ecology and physics of bacterial chemotaxis in the ocean. Microbiol. Mol. Biol. Rev. 76:792. doi: 10.1128/MMBR.00029-12

Stocker, R., Seymour, J. R., Samadani, A., Hunt, D. H., and Polz, M. F. (2008). Rapid chemotactic response enables marine bacteria to exploit ephemeral microscale nutrient patches. Proc. Natl. Acad. Sci. U.S.A. 105, 4209-4214. doi: 10.1073/pnas.0709765105

Subramaniam, A., Yager, P. L., Carpenter, E. J., Mahaffey, C., Bjorkman, K., Cooley, S., et al. (2008). Amazon river enhances diazotrophy and carbon sequestration in the tropical North Atlantic Ocean. Proc. Natl. Acad. Sci. U.S.A. 105, 10460-10465. doi: 10.1073/pnas.0710279105

Sul, W. J., Oliver, T. A., Ducklow, H. W., Amaral-Zettler, L. A., and Sogin, M. L. (2013). Marine bacteria exhibit a bipolar distribution. Proc. Natl. Acad. Sci. U.S.A. 110, 2342-2347. doi: 10.1073/pnas.1212424110

Tang, K. W., Smith, W. O. Jr., Elliott, D. T., and Shields, A. R. (2008). Colony size of Phaeocystis antarctica (Prymnesiophyceae) as influenced by zooplankton grazers. J. Phycol. 44, 1372-1378. doi: 10.1111/j.1529-8817.2008.00595.x

Teeling, H., Fuchs, B. M., Becher, D., Klockow, C., Gardebrecht, A., Bennke, C. M., et al. (2012). Substrate-controlled succession of marine bacterioplankton populations induced by a phytoplankton bloom. Science 336, 608-611. doi: $10.1126 /$ science. 1218344

Thioulouse, J., Chessel, D., Dole, S., and Olivier, J.-M. (1997). ADE-4: a multivariate analysis and graphical display software. Stat. Comput. 7, 75-83. doi: 10.1023/A:1018513530268

Thomas, F., Hehemann, J.-H., Rebuffet, E., Czjzek, M., and Michel, G. (2011). Environmental and gut bacteroidetes: the food connection. Front. Microbiol. 2:93. doi: $10.3389 /$ fmicb.2011.00093
Turner, J., Colwell, S. R., Marshall, G. J., Lachlan-Cope, T. A., Carleton, A. M., Jones, P. D., et al. (2005). Antarctic climate change during the last 50 years. Int. J. Climatol. 25, 279-294. doi: 10.1002/joc.1130

Van Boekel, J. S. W., and Stefels, W. H. M. (1993). Production of DMS from dissolved DMSP in axenic cultures of the marine phytoplankton species Phaeocystis sp. Mar. Ecol. Prog. Ser. 97, 11-18. doi: 10.3354/meps 097011

Van Mooy, B. A., Hmelo, L. R., Sofen, L. E., Campagna, S. R., May, A. L., Dyhrman, S. T., et al. (2011). Quorum sensing control of phosphorus acquisition in Trichodesmium consortia. ISME J. 6, 422-429. doi: 10.1038/ismej. 2011.115

Vogt, M., O’Brien, C., Peloquin, J., Schoemann, V., Breton, E., Estrada, M., et al. (2012). Global marine plankton functional type biomass distributions: Phaeocystis spp. Earth Syst. Sci. Data 4, 107-120. doi: 10.5194/essd-4107-2012

West, N. J., Obernosterer, I., Zemb, O., and Lebaron, P. (2008). Major differences of bacterial diversity and activity inside and outside of a natural iron-fertilized phytoplankton bloom in the Southern Ocean. Environ. Microbiol. 10, 738-756. doi: 10.1111/j.1462-2920.2007.01497.x

Wilkins, D., Lauro, F. M., Williams, T. J., Demaere, M. Z., Brown, M. V., Hoffman, J. M., et al. (2013a). Biogeographic partitioning of Southern Ocean microorganisms revealed by metagenomics. Environ. Microbiol. 15, 1318-1333. doi: $10.1111 / 1462-2920.12035$

Wilkins, D., Yau, S., Williams, T. J., Allen, M. A., Brown, M. V., Demaere, M. Z., et al. (2013b). Key microbial drivers in Antarctic aquatic environments. FEMS Microbiol. Rev. 37, 303-335. doi: 10.1111/1574-6976.12007

Williams, T. J., Wilkins, D., Long, E., Evans, F., Demaere, M. Z., Raftery, M. J., et al. (2013). The role of planktonic Flavobacteria in processing algal organic matter in coastal East Antarctica revealed using metagenomics and metaproteomics. Environ. Microbiol. 15, 1302-1317. doi: 10.1111/1462-2920. 12017

Wolf, C., Frickenhaus, S., Kilias, E. S., Peeken, I., and Metfies, K. (2013). Regional variability in eukaryotic protist communities in the Amundsen Sea. Antarct. Sci. 25, 741-751. doi: 10.1017/S0954102013000229

Yager, P. L., Sherrell, L., Stammerjohn, S. E., Alderkamp, A.-C., Schofield, O., Abrahamsen, E. P., et al. (2012). ASPIRE: the Amundsen Sea Polynya international research expedition. Oceanography 25, 40-53. doi: 10.5670/oceanog.2012.73

Zingone, A., Chrétiennot-Dinet, M. J., Lange, M., and Medlin, L. (1999). Morphological and genetic characterization of Phaeocystis cordata and P. jahnii (Prymnesiophyceae), two new species from the Mediterranean Sea. J. Phycol. 35, 1322-1337. doi: 10.1046/j.1529-8817.1999.3561322.x

Conflict of Interest Statement: The authors declare that the research was conducted in the absence of any commercial or financial relationships that could be construed as a potential conflict of interest.

Received: 06 July 2014; accepted: 07 November 2014; published online: 19 December 2014.

Citation: Delmont TO, Hammar KM, Ducklow HW, Yager PL and Post AF (2014) Phaeocystis antarctica blooms strongly influence bacterial community structures in the Amundsen Sea polynya. Front. Microbiol. 5:646. doi: 10.3389/fmicb.2014.00646 This article was submitted to Systems Microbiology, a section of the journal Frontiers in Microbiology.

Copyright (c) 2014 Delmont, Hammar, Ducklow, Yager and Post. This is an openaccess article distributed under the terms of the Creative Commons Attribution License (CC BY). The use, distribution or reproduction in other forums is permitted, provided the original author(s) or licensor are credited and that the original publication in this journal is cited, in accordance with accepted academic practice. No use, distribution or reproduction is permitted which does not comply with these terms. 